\title{
Development Study of Perceived Institutionalization and Perceived Performance Scales
}

\section{Studija razvoja ljestvica za percipiranu institucionalizaciju i percipirani učinak}

\author{
Original scientific paper • Izvorni znanstveni rad \\ Received-prispjelo: 11. 12. 2019. \\ Accepted-prihvaćeno: 14. 1. 2021. \\ UDK: $630 * 79$ \\ https://doi.org/10.5552/drvind.2021.1972
}

\author{
(C) 2021 by the author(s). \\ Licensee Faculty of Forestry and Wood Technology, University of Zagreb. \\ This article is an open access article distributed \\ under the terms and conditions of the \\ Creative Commons Attribution (CC BY) license.
}

\begin{abstract}
Institutionalization is necessary for corporations to prevent economic, financial, legal, administrative, and technical chaos and thus improve performance. The concept of performance is the most supporting tool in conducting the control function in business management. While the amount of input and products in the forest industry in Turkey is rising, institutionalization is inadequate. This study attempts to methodologically develop and test scales for perceived institutionalization and perceived performance in furniture and panel businesses, which are two sub-sectors of the forest industry. Data was obtained in 35 cities between March and July 2017, through face-to-face interviews with 797 employees in 462 furniture businesses and 31 panel businesses. In the analysis of the study, content validity of the scales was evaluated through expert opinion and initial application, while construct validity was assessed by EFA and CFA. Cronbach alpha coefficient, CR, and AVE were used to evaluate reliability, while the suitability of perceived institutionalization and performance scale model was assessed through SEM. The scales have high reliability and validity, and an improvement in the institutionalization level of a business will result in improvements in performance $(r=0.98)$. Through this methodological study, scales for perceived institutionalization and perceived performance in furniture and panel businesses operating in Turkey and the relationship between perceived institutionalization and perceived performance were explained by a model.
\end{abstract}

Keywords: perceived institutionalization; perceived performance; furniture and board sector; methodological study; structural equation model; Turkey

SAŽETAK • Institucionalizacija je nužan preduvjet za sprečavanje ekonomskoga, financijskog, pravnog, administrativnog i tehničkog kaosa korporacija te za poboljšanje njihova učinka. Koncept učinka najpouzdaniji je alat u provođenju kontrole poslovnog upravljanja. Dok količina sirovine i proizvoda u drvnoj industriji u Turskoj raste, institucionalizacija je neadekvatna. Ovim se istraživanjem pokušavaju metodološki razviti i testirati ljestvice za percipiranu institucionalizaciju i percipirani učinak poduzeća za proizvodnju namještaja i proizvodnju ploča, što su dva podsektora drvne industrije. Podatci su dobiveni u 35 gradova između ožujka i srpnja 2017., i to putem osobnih razgovora sa 797 zaposlenika u 462 tvrtke za proizvodnju namještaja i u 31 tvrtki za proizvodnju ploča. $U$ analizi ovog istraživanja ocijenjena je valjanost sadržaja ljestvica na temelju stručnog mišljenja i inicijalne

\footnotetext{
${ }^{1}$ Author is assistant professor at Karamanoğlu Mehmetbey University, Vocational School of Technical Sciences, Department of Machine and Metal Technologies, Production Quality Control Program, Karaman, Turkey.

${ }^{2}$ Author is associated professor at Düzce University, Faculty of Forestry, Department of Forest Industrial Engineering, Düzce, Turkey.

* This paper is author Ahmet Bora Kırklıkçı's Ph. D thesis. Assoc. Prof. Tarık Gedik is thesis advisor.
} 
primjene, dok je valjanost konstrukcije procijenjena uz pomoć EFA-e i CFA-e. Za procjenu pouzdanosti primijenjeni su Chronbachov alfa-koeficijent, CR i AVE, a prikladnost modela ljestvice za percipiranu institucionalizaciju $i$ učinak procijenjeni su uz pomoć SEM-a. Ljestvice imaju visoku pouzdanost i valjanost, a poboljšanje na razini institucionalizacije poduzeća donijet će i poboljšanje učinka tvrtke $(r=0,98)$. Ovim su metodološkim istraživanjem objašnjene ljestvice za percipiranu institucionalizaciju i percipirani učinak poduzeća za proizvodnju namještaja $i$ proizvodnju ploča koja posluju u Turskoj te prikazan odnos između percipirane institucionalizacije i percipiranog učinka.

Ključne riječi: percipirana institucionalizacija; percipirani učinak; sektor proizvodnje namještaja $i$ ploča; metodološko istraživanje; model strukturne jednadžbe; Turska

\section{INTRODUCTION}

1. UVOD

\subsection{Institutionalization, performance and productivity}

1.1. Institucionalizacija, učinak i produktivnost

According to Knight (1992), institutions are defined as "a set of rules that structure social interactions in particular ways in a society and of which knowledge is shared by members of the community". Institutionalists define institutions not in the narrow sense of formal organizations, but in the broader context of socially predetermined behavior as "the widespread and constant way of thinking or acting, which is implanted in habits of a group or in customs of the people" (Dayneko et al., 2014). Four general criteria, developed by Huntington (1973), allow us to assess the level of institutionalization of an institution. These are autonomy, adaptability, complexity and coherence. It was noted that these four criteria could be applied to institutional arrangements and are roadmaps for the transformation period that institutions need in order to influence their members and environments and survive.

The concept of "institutional" generally represents the characteristics of institutionalized organizations (Uygun et al., 2013). Institutionalization is, however, defined differently in the literature. Institutionalization is defined as the process by which an activity becomes generally accepted or routinized and is then handled in a regularized, structured, and systematic manner (Fuchs and Anderson, 1987). Institutionalization processes involve forming of an official structure, creation of unofficial norms, development of non-personal/objective procedures, focusing on administrative rituals, ideologies, legalization and legitimization. Thus, institutional theory traces the emergence of distinctive forms, processes, strategies, outlooks, and competences as they emerge from patterns of organizational interaction and adaptation (Selznick, 1996).

Through institutionalization, businesses adapt to their business world and this harmony increases performance. Institutional pressures, which compel businesses to institutionalization, have a long-term and extensive impact on administrative performance. As these institutions have the funds provided by entrepreneurs, they spend more effort to accomplish their goals (Han et al., 2016; Zhu and Sarkis, 2007). On the other hand, perceived business performance is measured by market share, turnover, profitability and institutional image indicators. These measurements can be performed by taking into consideration components such as market (e.g. market share), accounting (e.g. turnover, sales, profitability) and social performance (e.g. company image).

\subsection{Institutionalization in forest industry}

1.2. Institucionalizacija u drvnoj industriji

The Forest industry plays an essential role in sustainable development, not only in terms of its specific raw material but also due to the ongoing globalization of the industry (Tuppura et al., 2013). It is noted that the transformations currently occurring in the forest industry are frequently spontaneous and inconsistent and are vastly affected by national, regional, economic and social policy reforms. It is emphasized that even in countries where the forest industry has progressed, the sector cannot respond sufficiently to the policy reforms that affect instructional transformation and that the level of institutionalization is low (Dayneko et al., 2014; Wanat et al., 2018). For instance, the forest industry in Finland has been accused of not being innovative due to insufficient research and development activities (Åkerman et al., 2010).

Data on the forest industry sector in Turkey displays a tendency to expand to new markets. Turkey has established import and export connections with more than 200 countries for forest products. In many subsectors in Turkey, most especially in furniture and panel production, foreign trade balance looks positive. Strong aspects of Turkish furniture and panel sectors in the international market are cheap labor and being close to the middle east market. Iraqi and Syrian markets are possible opportunities for this sector (Serin and Şahin, 2018; İstek et al., 2017). Hence, Turkey has a $0.5 \%$ share of the 128-billion-dollar world woodbased product export, while amounting to $1 \%$ of 132-billion-dollar world wood-based products import. The forest products sector comprises $2.4 \%$ of the added value created in the production sector in Turkey (WMBA, 2017). Turkey's share in world furniture production is around $1 \%$ and it is rapidly increasing. In 2015, 16-billion-dollar worth of production had been achieved in the furniture sector and it was predicted that this figure would reach 22 billion dollars in 2018 (UCCET, 2017). Total furniture export reached 2.4 billion dollars in 2017 and its share in exports was $2.2 \%$. In 2018, it increased significantly, reaching 3.4 billion dollars. Turkey's share in world furniture export in 
2019 was $1.6 \%$. Furniture imports decreased by $6.6 \%$ in 2019, compared to the previous year. (TMT, 2020). Total panel production in 2016 was 9.2 million square meters, with only $10-15 \%$ of this being exported (JFIB, 2019). The furniture industry capacity usage ratio was $72 \%$ for 2016 (IIBA, 2018). The capacity usage ratio in the panel sector ranged between $75-85 \%$, and the total installed capacity was 12 million square meters. The installed capacity of the panel sector was 5 million square meter/year in particle board, 7 million square meters/year in medium-density fiberboard (MDF) and 240 thousand square meters in Oriented Strand Board (OSB) (JFIB, 2019). According to figures of General Census of Industry and Business Establishments, the furniture sector employed 133 thousand people, while the panel sector employed 13 thousand people (UCCET, 2015).

Small and medium-sized enterprises in the forest products industry, however, face threats such as a low level of state support (Sarıkahya, 2012), insufficient utilization of national and international financing opportunities, the necessity to import raw materials and have an inadequate number of qualified employees, regional instability, lack of design and adverse effects of Chinese furniture sector (Serin and Şahin, 2018).

While the amount of input and products in forest industry in Turkey are rising, institutionalization, the effectiveness of quality assurance systems, viability of European Union (EU) legislations and research and development expenditure are inadequate (Koç et al., 2017). Due to the rapid growth in the furniture industry in recent years, it is necessary for businesses to innovate their administrative activities and establish quality assessment systems (Altınok and Saçl1, 2009). Thus, it is noted that only basic quality control methods are implemented in the furniture industry, while quality control activities are more systematic and intense in fiber and particle board producers (Cindik et al., 1999). It seems necessary to focus on more advanced competitive elements such as research and development, design and marketing in order to strengthen the competitiveness of the sector and ensure its continuity.

Considering all this data, there is a close connection between business performance and institutionalization in furniture and panel businesses. From this point of view, this study attempts to determine the level of institutionalization of furniture and panel businesses, which are two sub-sectors of the forest industry. Scales for Perceived Institutionalization Scale (PIS) and Perceived Performance Scale (PPS) at the sectoral level were developed and tested methodologically.

Accordingly, the hypotheses below, which are related to independent (institutionalization) and dependent (performance) variables and sub-variables, were made.

$\mathrm{H}_{1} 1$, There is a relationship between consistency and institutionalization.

$\mathrm{H}_{1} 2$, There is a relationship between formalization and institutionalization.

$\mathrm{H}_{1} 3$, There is a relationship between transparency, accountability, and institutionalization.
$\mathrm{H}_{1} 4$, There is a relationship between productivity and performance.

$\mathrm{H}_{1} 5$, There is a relationship between operating income and performance.

$\mathrm{H}_{1} 6$, There is a relationship between product development and performance.

$\mathrm{H}_{1} 7$, There is a relationship between institutionalization and performance.

\section{MATERIALS AND METHODS}

2. MATERIJALI I METODE

\subsection{Data}

2.1. Podatci

The data of the study consists of 2622 furniture and panel businesses registered in UCCET and the Turkish Particle Board Industrialists Association (TPBIA) in 2016. The data of the study is the businesses with ten or more employees within the enterprises mentioned above. The sample size was determined as 346 with a 5 $\%$ margin of error and a $95 \%$ level of confidence by means of sampling formula for limited sample groups. The study population was obtained by a stratified sampling method which is set for geographical regions. Data was obtained in 35 cities between March and July 2017, through face to face interviews with 797 employees in 493 businesses, $93.7 \%$ of which (462) are furniture and $6.3 \%$ (31) are panel businesses. While $60.2 \%$ (297) of these businesses employ 10-49 people, $23 \%$ (118) of them have 50-149, $6.7 \%$ (33) of these establishments work with 150-249 employees, and 9.1\% (45) employs more than 250 workers.

\subsection{Development steps of PIS and PPS \\ 2.2. Koraci razvoja PIS-a i PPS-a}

\subsubsection{Generating the item pool}

\subsubsection{Stvaranje skupa teza}

In this step, postgraduate theses in the Council of Higher Education in both Turkish and foreign languages, which include the keywords of institutionalization, corporate governance, performance in their subject of study or name, were scanned. Three hundred fifty-five theses written before 2016 were found. One hundred and seventy of these theses were about institutionalization, 185 of them were about performance. In addition to this, 400 different studies (articles, notices, reports, etc.), which were accessed by scanning through Science Direct and Google Scholar on the internet, were analyzed. One thousand six hundred ninety-nine items included in these separate studies in the literature were listed, compared, and checked for repetitions, which resulted in a pool of 71 items after the omission of repeated items (Table 1). In order to express the level of agreement on the items in the list, 5-point Likert scale ("1" Strongly Disagree, "2" Disagree, "3" Undecided, "4" Agree, "5" Strongly Agree) was used.

\subsubsection{Expert opinion (content validity)}

2.2.2. Stručno mišljenje (valjanost sadržaja)

Items in the pool were proved by twelve experts (forest industry engineering academic members) to at- 
tain content validity. Experts did not call for any changes in the item number but provided suggestions on their content. Necessary editing was completed before pre-application.

Table 1 Item pool related to perceived institutionalization and perceived performance

Tablica 1. Skup teza vezanih za percipiranu institucionalizaciju i percipirani učinak

\begin{tabular}{|c|c|}
\hline $\begin{array}{l}\text { Categories } \\
\text { Kategorije }\end{array}$ & Item pool / Skup teza \\
\hline $\begin{array}{l}\text { Institutionalization } \\
\text { institucionalizacija }\end{array}$ & 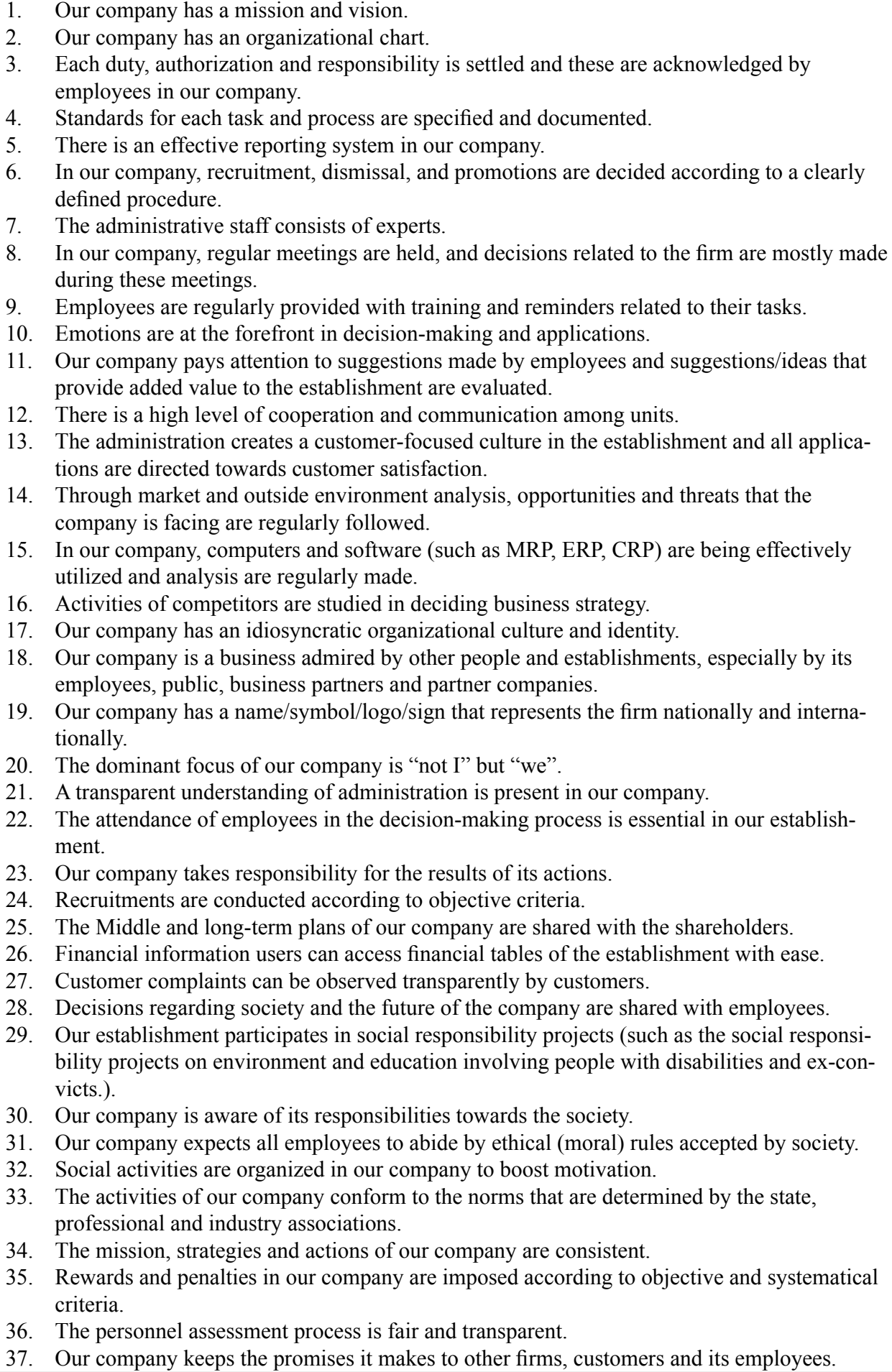 \\
\hline
\end{tabular}


Table 1 Item pool related to perceived institutionalization and perceived performance (continuation)

Tablica 1. Skup teza vezanih za percipiranu institucionalizaciju i percipirani učinak (nastavak)

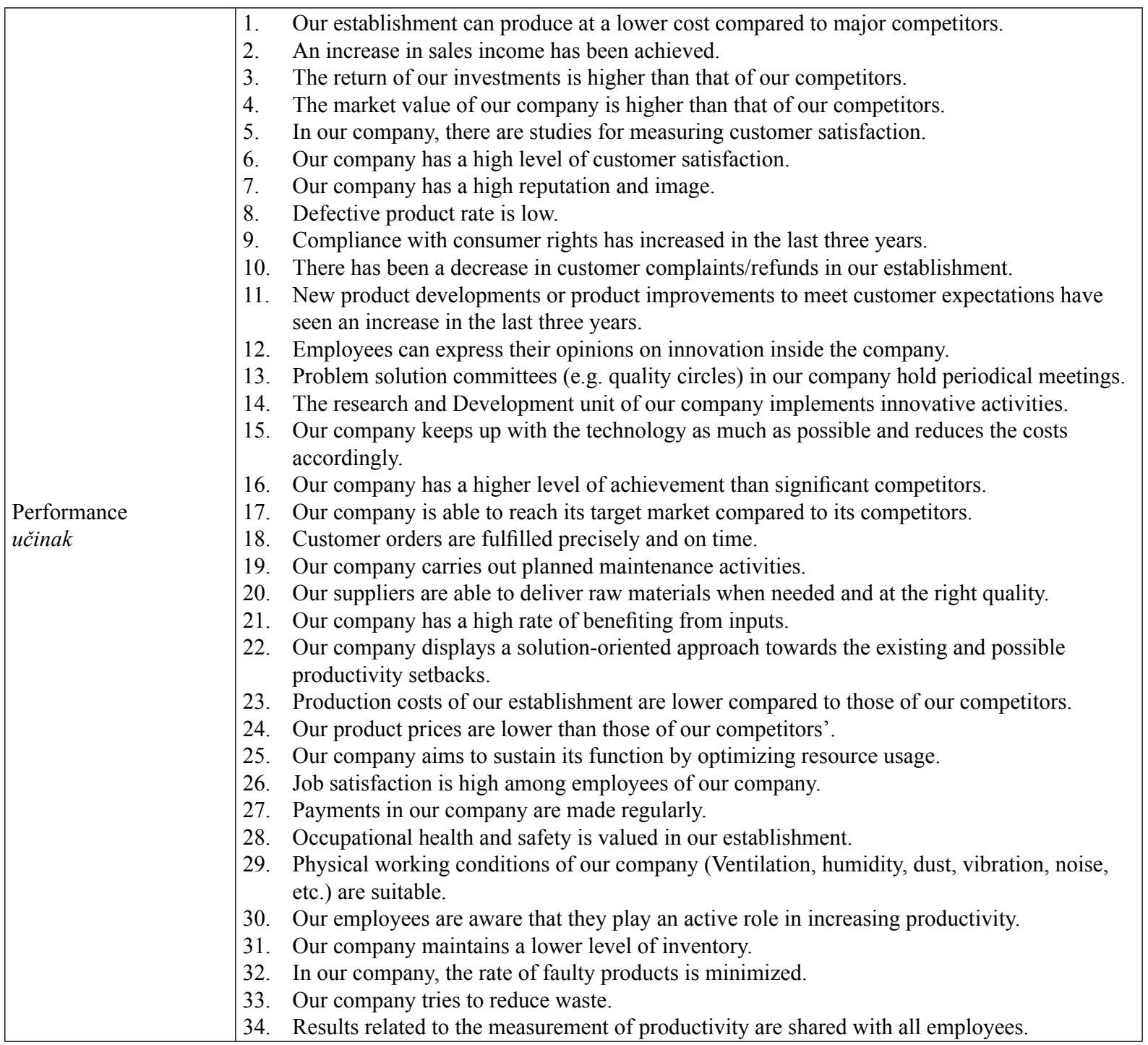

\subsubsection{Initial application}

\subsubsection{Inicijalna primjena}

Items designated according to expert opinion were tested in Konya by face to face interviews with 100 people in the production business active in 22 different sectors. After the analysis, it was concluded that the items had no cases of absence of perception and that none of the items needed to be removed or added.

\subsubsection{Factor and reliability analysis}

\subsubsection{Analiza faktora i pouzdanosti}

After the draft scale was applied on 797 people working in 493 furniture and panel businesses, explanatory factor analysis (EFA) was implemented. According to the results of the analysis, items demonstrating construct validity were listed in the final scale. Cronbach Alpha internal consistency coefficient was calculated for the finalized scale. Calculations were made in SPSS 22 (IBM corp., 2013). In order to test the suitability of the structure, which was created through explanatory factor analysis, a confirmatory factor analysis (CFA) was conducted using AMOS 22 (Arbuckle,
2013). It is suggested that EFA should be applied initially in scale development phase, followed by CFA to confirm these new factor structures discovered (Yaşlıoğlu, 2017). In this respect, in order to determine in which sub-dimension or conceptual framework the items were perceived by the participants in the businesses, EFA, which is a process used to discover factors, was used considering the relationships between variables in the first step. The data to be used in factor analysis must display a normal distribution pattern. As a result, it was assumed that skewness-kurtosis coefficients demonstrated normality between -3 and +3 (Bentler, 2006). After the designation of factors constituting the scale, a suitable title for each factor was chosen according to expressions related to items included in every factor. CFA was implemented to test the model determined after EFA application.

\subsubsection{Structural equation modeling (SEM) \\ 2.2.5. Modeliranje strukturnih jednadžbi (SEM)}

Structural equation modeling (SEM) is a robust analysis as it enables us to study interrelations of implicit along with observed variables, conduct many 
Table 2 SEM fit indexes

Tablica 2. SEM indeksi prikladnosti

\begin{tabular}{|l|c|c|c|c|c|c|c|}
\hline $\begin{array}{l}\text { Fit index* } \\
\text { Indeks prikladnosti* }\end{array}$ & $\chi^{2} / \mathbf{d f}$ & NFI & CFI & RMSEA & GFI & AGFI & RMR \\
\hline $\begin{array}{l}\text { Good fit } \\
\text { dobra prikladnost }\end{array}$ & $0 \leq \chi^{2} / \mathrm{df} \leq 3$ & $0.95-1.00$ & $0.95-1.00$ & $0.00-0.05$ & $0.90-1.00$ & $0.90-1.00$ & $0.00-0.05$ \\
\hline $\begin{array}{l}\text { Acceptable fit } \\
\text { prihvatljiva prikladnost }\end{array}$ & $3 \leq \chi^{2} / \mathrm{df} \leq 5$ & $0.90-0.94$ & $0.90-0.94$ & $0.06-0.08$ & $0.85-0.89$ & $0.85-0.89$ & $0.06-0.08$ \\
\hline
\end{tabular}

*AGFI - Adjusted Goodness of Fit Index, CFI - Comparative Fit Index, GFI - Goodness of Fit Index, NFI - Normed Fit Index, $\chi 2 / d f-C h i$ Square/Degree of Freedom, RMR - Root Mean Square Residual, RMSEA - Root Mean Square Error of Approximation

*AGFI - prilagodeni indeks prikladnosti, CFI - usporedni indeks prikladnosti, GFI - indeks prikladnosti, NFI - normirani indeks prikladnosti, $\chi 2 / d f$ - Hi-kvadrat/stupanj slobode, RMR - korijen srednjeg kvadrata ostatka, RMSEA - korijen iz prosječne kvadrirane pogreške aproksimacije

analyses simultaneously, structure models and speculate on them. Fit indexes used to interpret SEM are given in Table 2 (Byrne, 2010; Schermelleh-Engel et al., 2003).

\subsection{Ethics \\ 2.3. Etika}

Written consent was obtained from the institutions. The purpose of the study was explained to the workers, and participation was allowed after their consent. It was explained that the information provided by the participants would only be used within the scope of the current study.

\subsection{Limitations of the study \\ 2.4. Ograničenja studije}

During the study, 50 cities were visited in total; however, due to time limitations, closed businesses, technical and economic difficulties and security issues, the survey study could only be conducted in 15 cities. All registered panel businesses were contacted, in addition to visiting almost 1000 businesses. As some businesses refused to participate, the survey was not conducted in these firms. The study is confined to the responses of 797 employees from 493 companies that participated in the survey.

\section{RESULTS AND DISCUSSION 3. REZULTATI I RASPRAVA}

\subsection{Demographic and workplace findings}

3.1. Demografski nalazi i nalazi na radnome mjestu

A high percentage of participants (75.7\%) (603) were male, $43.3 \%$ (345) were within $26-35$ years of age, $70 \%$ of the participants (558) were married, and $47.9 \%$ (382) were university graduates. Almost half of the participants (48\%) (357) were directors, $31.9 \%$ (254) had worked between 1 and 3 years for the same company, and $46.7 \%$ (372) had been working in the same sector for more than 10 years. Similar to the demographics given in this study, a study conducted in the forest products industry in Turkey determined that most of $432 \mathrm{em}-$ ployees involved were university graduates (48\%), male (83\%), between $26-35(50 \%)$, married (70\%) and at upper and middle levels (49\%). While the rate of employees working for ten or more years was $16 \%$ in the same study, the rate of experienced workers in this study is higher (Aydın and Tiryaki, 2018).

\subsection{Suitability assessment of data for factor} analysis

3.2. Procjena prikladnosti podataka za faktorsku analizu

Kaier-Meyer-Olkin (KMO) and Barlett test were used to determine whether the data obtained from the study group was suitable for EFA. In this study, Cronbach Alpha Coefficient for PIS is 0.959, KMO value is 0.970 , Barlett value is equal to 16896.501 . For PPS, Cronbach Alpha Coefficient is 0.942 , KMO value is 0.951 and Barlett value is 13832.059 . These results show that the scales have high reliability and validity (Yaşar, 2014).

\subsection{Determining the factor pattern of PIS}

3.3. Određivanje uzorka faktora PIS-a

It was detected that item 19 in the PIS did not demonstrate normal distribution and thus was removed from the analysis. It was calculated that the coefficient of kurtosis ranged between -1.075 and +2.889 , while the skewness coefficient had values between -1.997 and -0.344 for the data used in perceived institutionalization. Therefore, it was concluded that these values displayed normal distribution. This three-factor structure accounts for $59.3 \%$ of the total variance.

In the study, the first factor lists items that emphasize the necessity of the firms to focus on consistency and on how important this is for the institutionalization, as well as the importance to keep the focus on these topics. The first factor was thus classified as "Consistency (c)" sub-dimension. Items 7 (c13), 11 (c12), 12 (c15), 13 (c9), 17 (c14), 18 (c4), 20 (c5), 21 (c8), 23 (c6), 24 (c7), 30 (c1), 31 (c3), 33 (c11), 34 (c10) and 37 (c2) belong to the first factor. Factor loads for these items range between 0.761 and 0.555 . The variance displayed by this factor is $29.4 \%$. Cronbach Alpha coefficient is 0.944 . The second factor was named "Formalization (f)" subdimension, due to the fact that the items belonging to this factor express that businesses should focus on formalization. Items 1 (f2), 2 (f1), 3 (f3), 4 (f5) and 5 (f4) were placed in the second factor and their factor loads range between 0.766 and 0.667 . Variance declared by this factor is $16.23 \%$. Cronbach Alpha Coefficient is 0.855 . Items expressing that the businesses should focus on transparency and accountability were mostly listed in the third virtual factor. Hence, this factor was named "Transparency and accountability (ta)" sub-dimension. Items number 25 (ta4), 28 (ta3), 32 (ta1) and 35 (ta2) belong to 
Table 3 Factor analysis results related to PIS

Tablica 3. Rezultati faktorske analize povezani s PIS-om

\begin{tabular}{|c|c|c|c|c|c|c|}
\hline Factors / Faktori & & & & & & \\
\hline & $\neq 30$ & 0.761 & $\neq 2$ & 0.766 & $\neq 32$ & 0.772 \\
\hline & $\neq 37$ & 0.742 & $\neq 1$ & 0.738 & $\neq 35$ & 0.662 \\
\hline & $\neq 31$ & 0.729 & $\neq 3$ & 0.708 & $\neq 28$ & 0.621 \\
\hline & $\neq 18$ & 0.722 & $\neq 5$ & 0.697 & $\neq 25$ & 0.528 \\
\hline & $\neq 20$ & 0.664 & $\neq 4$ & 0.667 & & \\
\hline & $\neq 23$ & 0.656 & & & & \\
\hline & $\neq 24$ & 0.648 & & & & \\
\hline Factor load & $\neq 21$ & 0.639 & & & & \\
\hline Opterecenje faktora & $\neq 13$ & 0.635 & & & & \\
\hline & $\neq 34$ & 0.622 & & & & \\
\hline & $\neq 33$ & 0.580 & & & & \\
\hline & $\neq 11$ & 0.579 & & & & \\
\hline & $\neq 7$ & 0.567 & & & & \\
\hline & $\neq 17$ & 0.561 & & & & \\
\hline & $\neq 12$ & 0.555 & & & & \\
\hline Eigen value / Vlastita vrijednost & & & & & & \\
\hline $\begin{array}{l}\text { Explanatory power of the factor, \% } \\
\text { Obrazloženje snage faktora, \% }\end{array}$ & & & & & & \\
\hline Reliability / Pouzdanost & & & & & & \\
\hline
\end{tabular}

the third factor and their factor loads range between 0.772 and 0.528 . Variance declared by this factor is 13.6 $\%$. Cronbach Alpha Coefficient is 0.727 . The fact that the explained variation exceeds $50 \%$ of the total variation is stated as an important criterion of factor analysis (Yaşlığlu, 2017). Accordingly, while the first factor subdimension is able to represent, the other two factor subdimensions have a lower potential of representation. Items 6, 8, 9, 10, 14, 15, 16, 22, 26, 27, 29 and 36 that do not return a meaningful result in any of the virtual factors, a lower load of a factor $(<0.50)$, return meaningful results for more than one virtual factor or exist alone in a virtual cluster are removed from the scale. Cronbach Alpha Coefficients are perfect fit for (c), a good level of fit for (f) and (ta) (Kalayc1, 2009) (Table 3).

\subsection{Determining the factor pattern of PPS}

3.4. Određivanje uzorka faktora PPS-a

It was detected that items 27 and 28 in the PPS did not demonstrate normal distribution and thus they were removed from the analysis. It was calculated that the coefficient of kurtosis ranged between -0.685 and +2.38 , while the skewness coefficient returned values between -2.035 and -0.242 for the data used in perceived institutionalization. Therefore, it was concluded that these values displayed normal distribution. The factor structure of the PPS is organized in three factors. This three-factor structure accounts for $57.1 \%$ of the total variance.

This factor, which consists of items expressing that the main focus of businesses should be productivity, was named as "Productivity (p)" sub-dimension. Items 7 (p4), 8 (p2), 12 (p13), 18 (p1), 19 (p9), 20 (p12), 21 (p10), 22 (p6), 25 (p11), 26 (p3), 29 (p7), 30 (p 35) and 33 (p8) belong to the first factor and their factor loads range between 0.744 and 0.521 . Variance displayed by this factor is $30.6 \%$. Cronbach Alpha coefficient is 0.925 . The second virtual factor, which consists of items related to profitability and efficiency in the study, is named as "Operating income (oi)" sub-

Table 4 Factor analysis results related to PPS

Tablica 4. Rezultati faktorske analize povezani s PPS-om

\begin{tabular}{|c|c|c|c|c|c|c|}
\hline Factors /Faktori & \multicolumn{2}{|c|}{ Factor I } & \multicolumn{2}{|c|}{ Factor II } & \multicolumn{2}{|c|}{ Factor III } \\
\hline $\begin{array}{l}\text { Factor load } \\
\text { Opterećenje faktora }\end{array}$ & $\begin{array}{c}\neq 18 \\
\neq 8 \\
\neq 26 \\
\neq 7 \\
\neq 30 \\
\neq 22 \\
\neq 29 \\
\neq 33 \\
\neq 19 \\
\neq 21 \\
\neq 25 \\
\neq 20 \\
\neq 12\end{array}$ & $\begin{array}{l}0.744 \\
0.734 \\
0.727 \\
0.716 \\
0.711 \\
0.707 \\
0.668 \\
0.663 \\
0.648 \\
0.637 \\
0.623 \\
0.605 \\
0.521\end{array}$ & $\begin{array}{l}\neq 3 \\
\neq 4 \\
\neq 16 \\
\neq 17 \\
\neq 2\end{array}$ & $\begin{array}{l}0.828 \\
0.769 \\
0.647 \\
0.604 \\
0.591\end{array}$ & $\begin{array}{l}\neq 14 \\
\neq 13 \\
\neq 15\end{array}$ & $\begin{array}{l}0.801 \\
0.722 \\
0.576\end{array}$ \\
\hline Eigen value / Vlastita vrijednost & \multicolumn{2}{|c|}{9.033} & \multicolumn{2}{|c|}{1.896} & \multicolumn{2}{|c|}{1.065} \\
\hline $\begin{array}{l}\text { Explanatory power of the factor, \% } \\
\text { Obrazloženje snage faktora, \% }\end{array}$ & \multicolumn{2}{|c|}{30.6} & \multicolumn{2}{|c|}{14.7} & \multicolumn{2}{|c|}{11.8} \\
\hline Reliability / Pouzdanost & \multicolumn{2}{|c|}{0.925} & \multicolumn{2}{|c|}{0.798} & \multicolumn{2}{|c|}{0.756} \\
\hline
\end{tabular}


dimension. Items 2 (oi5), 3 (oi1), 4 (oi2), 16 (oi3) and 17(oi4) are placed in the second factor and their factor loads range between 0.828 and 0.591 . Variance declared by this factor is $14.7 \%$. Cronbach Alpha Coefficient is 0.798 . Items related to product development are listed in this factor, and thus it is named "Product development (pd)" sub-dimension. Items number 13 (pd2), 14 (pd1) and 15(pd3) belong to the third factor and their factor loads range between 0.801 and 0.576 . Variance declared by this factor is $11.8 \%$. Cronbach Alpha Coefficient is 0.756. Accordingly, while the first-factor sub-dimension is able to represent, the other two factor sub-dimensions have a lower potential of representation. (Yaşlığlu, 2017). Items 1, 5, 6, 9, 10, $11,23,24,31,32$ and 34 that do not return a meaningful result in any of the virtual factors, a lower load of a factor $(<0.50)$, return meaningful results for more than one virtual factor or exist alone in a virtual cluster are removed from the scale. Cronbach Alpha Coefficients have a perfect fit for $(p)$, while maintaining a good level of fit for (oi) and (pd) (Kalaycı, 2009) (Table 4).

\subsection{Confirmatory factor analysis of PIS}

\subsection{Potvrdna analiza faktora PIS-a}

According to the results of CFA of PIS, GFI was found as 0.90 , AGFI as 0.88 , RMR as 0.045 , NFI as 0.91 and CFI as 0.94. NFI and CFI indexes lower than 0.95 and AGFI index lower than 0.90 prove an acceptable fit, while RMR below 0.05 and GFI showing 0.90 mean a good fit. (Byrne, 2010; Schermelleh-Engel et al., 2003).

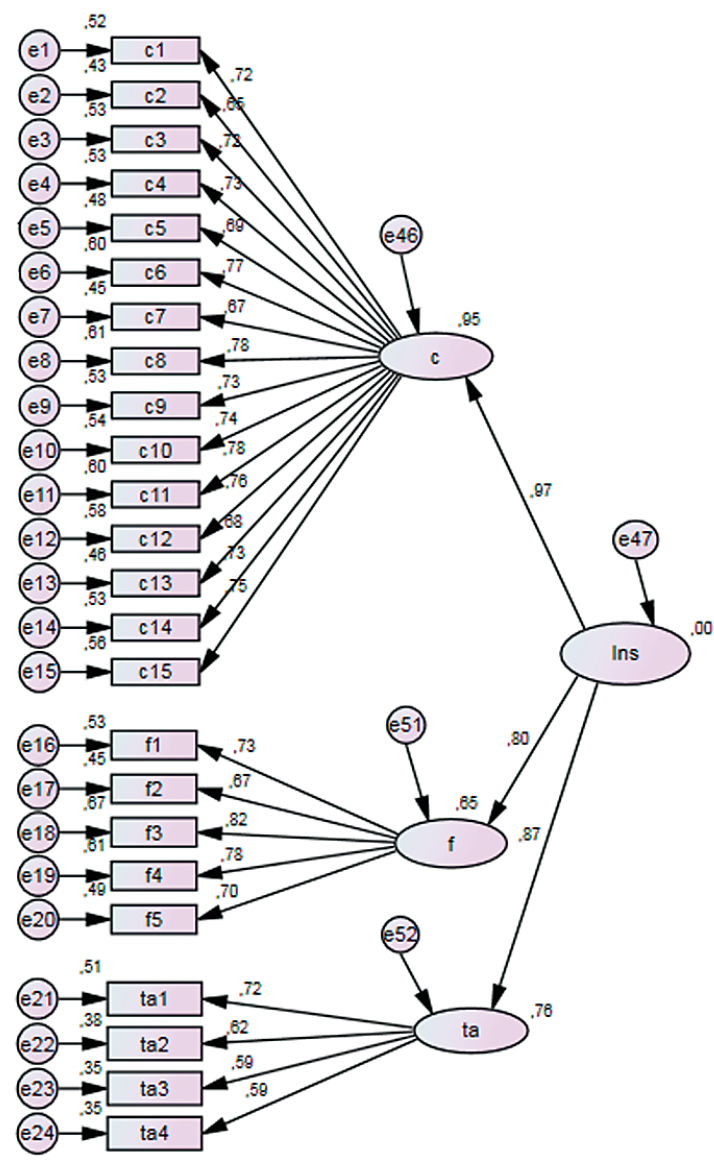

Figure 1 Path diagram related to PIS Slika 1. Dijagram toka za PIS
In the diagram illustrated according to the analysis conducted, correlation coefficients related to the items range between 0.59 and 0.82 . The ratio of ChiSquare value to the degree of freedom is $\left(\chi^{2} / \mathrm{df}\right) 3.90$. Results in the range between 3 and 5 can be interpreted as an acceptable fit. Considering RMSEA results, 0.06 can be seen as an acceptable fit (Schermelleh-Engel et al., 2003). Based on the data obtained as a result of CFA, it is safe to say that 3-factor PIS is confirmed as a model. For the model to have better fit values, modification indices (MI) covariance values among disturbance terms under the same factors were studied (Yaşlığlu, 2017). Some changes were made according to disturbance covariances between c5-c6 and c10-c13 as the software suggested. PIS was confirmed as a model (Figure 1).

\subsection{Confirmatory factor analysis of PPS 3.6. Potvrdna analiza faktora PPS-a}

According to the results of CFA of PPS, GFI was found as 0.93 , AGFI as 0.91 , RMR as 0.04 , NFI as 0.92 and CFI as 0.95. CFI equal to 0.95, AGFI index over 0.90 , RMR lower than 0.05 and GFI value over 0.90 display good fit, NFI value being lower than 0.95 corresponds to an acceptable fit (Byrne, 2010; Schermelleh-Engel et al., 2003).

In the diagram generated with the results of the analysis conducted, correlation coefficients related to the items range between 0.50 and 0.84 . The ratio of Chi-Square value to the degree of freedom is $\left(\chi^{2} / \mathrm{df}\right)$ 3.47. Results in the range between 3 and 5 can be inter-

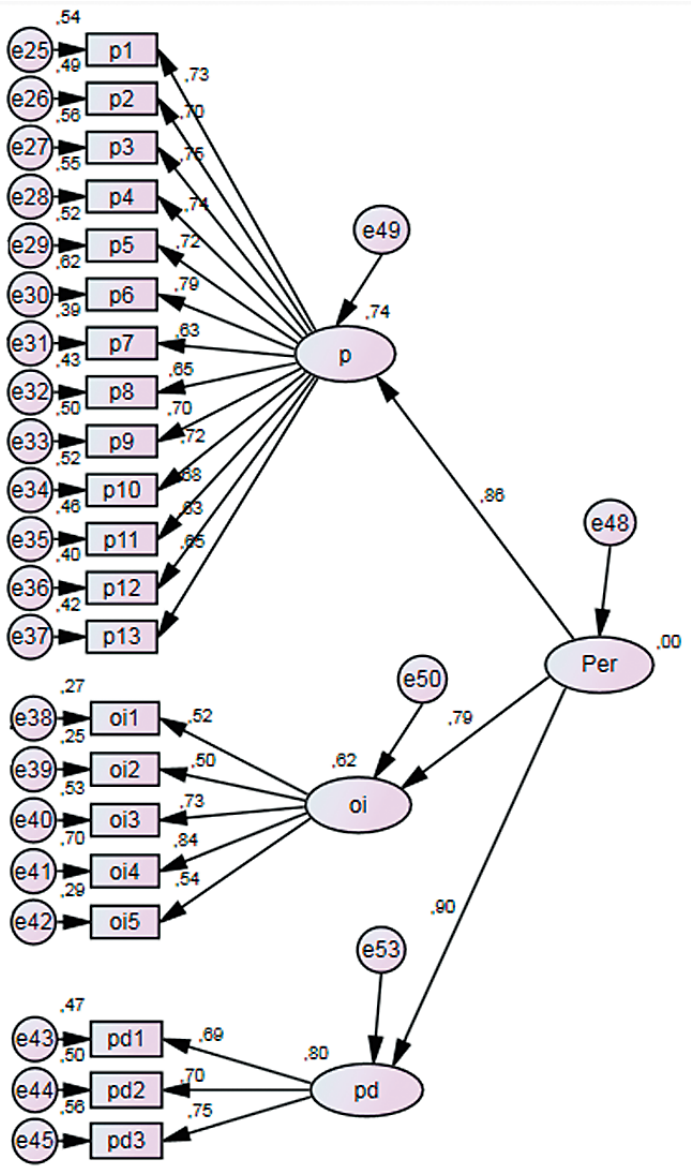

Figure 2 Path diagram related to PPS

Slika 2. Dijagram toka za PPS 
preted as an acceptable fit. Considering RMSEA results, it was seen that a fit index on the level of 0.05 was achieved. RMSEA value lower than 0.06 can be interpreted as a good fit (Schermelleh-Engel et al., 2003). In the established model, some changes were made considering disturbance covariances between $\mathrm{p} 5$ p7, oil-oi2 and oil-oi5. Based on the data obtained as a result of CFA, it can be stated that three-factor PPS is confirmed as a model (Figure 2).

\subsection{Reliability values of PIS and PPS}

3.7. Vrijednosti pouzdanosti za PIS i PPS

For convergent validity test, composite reliability (CR) and Average Variance Extracted (AVE) were calculated and shown along with standard loading and $\mathrm{t}$ values (Table 5). Fornell and Larcker (1981) suggest that composite reliability (CR) should be over 0.70 , while AVE value is over 0.50 for a better convergent validity. Accordingly, for PIS, while CR values of all sub-dimensions prove a good fit, AVE value is lower than expected in only (ta) sub-dimension. When we consider PPS, CR values prove a good fit in all subdimensions while AVE value proved to be low in only (oi) sub-dimension. On the other hand, it was also stated that construct validity is at a sufficient level when AVE is lower than 0.50 only if CR value is higher than 0.60 (Huang et al., 2013).

\subsection{Correlation matrix for scales and sub-scales} 3.8. Korelacijska matrica za ljestvice i podljestvice

The correlations among the institutionalization and sub-scales and performance and sub-scales are presented in Table 6 along with a discriminant validity test.

Table 5 Reliability values of PIS and PPS

Tablica 5. Vrijednosti pouzdanosti za PIS i PPS

\begin{tabular}{|c|c|c|c|c|c|c|c|}
\hline $\begin{array}{l}\text { Institutionalization } \\
\text { Institucionalizacija }\end{array}$ & $\begin{array}{l}\text { Items } \\
\text { Teze }\end{array}$ & $\begin{array}{l}\text { Standard } \\
\text { loading } \\
\text { Standardno } \\
\text { opterećenje }\end{array}$ & $t^{*}$ & $\begin{array}{l}\text { Performance } \\
\text { Učinak }\end{array}$ & $\begin{array}{l}\text { Items } \\
\text { Teze }\end{array}$ & $\begin{array}{l}\text { Standard } \\
\text { loading } \\
\text { Standardno } \\
\text { opterećenje }\end{array}$ & $t^{*}$ \\
\hline \multirow{15}{*}{$\begin{array}{l}\text { Consistency } \\
\text { dosljednost } \\
(\mathrm{CR}=0.94, \mathrm{AVE}=0.53)\end{array}$} & $\mathrm{c} 1$ & 0.722 & 21.843 & \multirow{13}{*}{$\begin{array}{l}\text { Productivity } \\
\text { produktivnost } \\
(\mathrm{CR}=0.93, \mathrm{AVE}=0.50)\end{array}$} & $\mathrm{p} 1$ & 0.735 & 21.099 \\
\hline & c2 & 0.652 & 19.351 & & $\mathrm{p} 2$ & 0.698 & 19.955 \\
\hline & c3 & 0.725 & 21.919 & & p3 & 0748 & - \\
\hline & $\mathrm{c} 4$ & 0.730 & 22.123 & & $\mathrm{p} 4$ & 0.739 & 21.228 \\
\hline & $\mathrm{c5}$ & 0.694 & 20.776 & & p5 & 0.719 & 20.583 \\
\hline & c6 & 0.773 & 23.728 & & p6 & 0.786 & 22.765 \\
\hline & c7 & 0.669 & 19.918 & & p7 & 0.628 & 17.758 \\
\hline & c8 & 0.781 & 24.047 & & $\mathrm{p} 8$ & 0.652 & 18.513 \\
\hline & c9 & 0.728 & 22.038 & & p9 & 0.705 & 20.158 \\
\hline & $\mathrm{c} 10$ & 0.737 & 22.382 & & p10 & 0.723 & 20.719 \\
\hline & $\mathrm{c} 11$ & 0.777 & - & & p11 & 0.680 & 19.385 \\
\hline & $\mathrm{c} 12$ & 0.760 & 23.236 & & p12 & 0.631 & 17.855 \\
\hline & $\mathrm{c} 13$ & 0.681 & 20.343 & & p13 & 0.650 & 18.459 \\
\hline & c14 & 0.726 & 21.957 & \multirow{5}{*}{$\begin{array}{l}\text { Operating income } \\
\text { operativni dohodak } \\
(\mathrm{CR}=0.77, \mathrm{AVE}=0.41)\end{array}$} & oi1 & 0.517 & 13.825 \\
\hline & $\mathrm{c} 15$ & 0.750 & 22.864 & & oi2 & 0.496 & 13.268 \\
\hline \multirow{5}{*}{$\begin{array}{l}\text { Formalization } \\
\text { formalizacija } \\
(\mathrm{CR}=0.86, \mathrm{AVE}=0.55)\end{array}$} & $\mathrm{f1}$ & 0.731 & 21.032 & & oi3 & 0.731 & 19.882 \\
\hline & $\mathrm{f} 2$ & 0.671 & 19.070 & & oi4 & 0.838 & - \\
\hline & $\mathrm{f3}$ & 0.816 & 23.820 & & oi5 & 0.540 & 14.522 \\
\hline & $\mathrm{f} 4$ & 0.781 & - & \multirow{3}{*}{$\begin{array}{l}\text { Product development } \\
\text { razvoj proizvoda } \\
(\mathrm{CR}=0.76, \mathrm{AVE}=0.51) \\
\end{array}$} & $\mathrm{pd} 1$ & 0.686 & 16.573 \\
\hline & f5 & 0.698 & 19.940 & & $\mathrm{pd} 2$ & 0.705 & - \\
\hline \multirow{4}{*}{$\begin{array}{l}\text { Transparency and accountability } \\
\text { transparentnost } i \text { odgovornost } \\
\mathrm{CR}=0.73, \mathrm{AVE}=0.40 \text { ) }\end{array}$} & tal & 0.717 & 14.865 & & $\mathrm{pd} 3$ & 0.745 & 17.656 \\
\hline & ta2 & 0.617 & 13.468 & & & & \\
\hline & ta3 & 0.593 & 13.088 & & & & \\
\hline & ta4 & 0.592 & - & & & & \\
\hline
\end{tabular}

*P values belonging to all $\mathrm{t}$ values is determined as $0.000 . / *$ Vrijednosti P koje pripadaju svim vrijednostima todređene su kao 0,000.

Table 6 Correlation matrix for scales and sub-scales

Tablica 6. Korelacijska matrica za ljestvice i podljestvice

\begin{tabular}{|c|c|c|c|c|c|c|c|c|}
\hline $\begin{array}{c}\text { Scales and sub-scales } \\
\text { Ljestvice i podljestvice }\end{array}$ & $\mathbf{c}$ & $\mathbf{f}$ & ta & ins & p & oi & pd & per \\
\hline $\mathrm{c}$ & 1 & & & & & & & \\
\hline $\mathrm{f}$ & 0.697 & 1 & & & & & & \\
\hline $\mathrm{ta}$ & 0.689 & 0.556 & 1 & & & & & \\
\hline $\mathrm{ins}$ & 0.899 & 0.857 & 0.868 & 1 & & & & \\
\hline $\mathrm{p}$ & 0.857 & 0.644 & 0.632 & 0.805 & 1 & & & \\
\hline $\mathrm{oi}$ & 0.476 & 0.487 & 0.450 & 0.539 & 0.521 & 1 & & \\
\hline $\mathrm{pd}$ & 0.626 & 0.585 & 0.622 & 0.699 & 0.636 & 0.523 & 1 & \\
\hline $\mathrm{per}$ & 0.768 & 0.678 & 0.677 & 0.807 & 0.840 & 0.798 & 0.881 & 1 \\
\hline
\end{tabular}




\subsection{Fit indexes for PIS and PPS}

3.9. Indeksi prikladnosti za PIS i PPS

Suitability of PIS and PPS model was tested by RMSEA, GFI, AGFI, RMR, NFI and CFI indexes. In consequence of the analysis, GFI value was found as 0.85 , AGFI as 0.85 , RMR as 0.047 , NFI as 0.90 and finally CFI was found equal to 0.91 . NFI and CFI indexes lower than 0.95 , GFI value equal to 0.85 and AGFI equal to 0.85 correspond to an acceptable fit, while RMR value below 0.05 indicates a good fit (Byrne, 2010; Schermelleh-Engel et al., 2003). In the diagram of the model generated with the results of the analysis conducted, the ratio of Chi-Square value to the degree of freedom is $\left(\chi^{2} / \mathrm{df}\right) 3.00$. A result equal to 3 can be interpreted as a good fit. RMSEA result that is equal to 0.05 demonstrates that a good fit measure has been obtained (Schermelleh-Engel et al., 2003). In the model established, some changes were made regarding disturbance covariance between c5-c6, c8-c11, c10c13, p5-p7, oi1-oi2 and oi1-oi5. A total of 45 observed variables were used in the model. 15 of these variables contain items related to (c), 5 of these contain (f), 4 covers (ta), 13 of them include (p), 5 represent (oi), while 3 of these variables demonstrate (pd). The number of implicit variables in the model is 6 in total.

The results of the model analysis show that seven hypotheses $(p<0.05)$ were accepted,

$\mathrm{H}_{1}$ 1. A positive and meaningful relation was detected between (c) and "Institutionalization" $(r=0.967)$. Therefore, $\mathrm{H}_{1} 1$ hypothesis is accepted. Şanal (2011) and Apaydın (2009) stated that consistency boosts institutionalization and business performance accordingly.

$\mathrm{H}_{1}$ 2. A positive and meaningful relationship was found between (f) and "Institutionalization" $(r=0.811)$. Therefore, $\mathrm{H}_{1} 2$ hypothesis is accepted. These regulations are thought to prevent confusion in duty assignments, conflicts of authorities and task setbacks along with increasing the performance (Gürüz and Gürel, 2009; Tengilimoğlu et al., 2012).

$\mathrm{H}_{1} 3$. An increase in (ta) has affected "Institutionalization" structure positively $(r=0.877)$. Therefore, $\mathrm{H}_{1}$ 3 hypothesis is accepted. Similar to the strong underlying relationships determined in the model, the positive effect of transparency and accountability in increasing the institutionalization in an establishment was also emphasized in previous studies (Gedik, 2010; Y1lmaz, 2006; Sözbilen, 2012).

$\mathrm{H}_{1}$ 4. A positive and meaningful relationship was found between (p) and "Performance" $(r=0.956)$. Therefore, $\mathrm{H}_{1} 4$ hypothesis is accepted. In their study on furniture and panel businesses, Kırklıkçı and Gedik (2019) determined that the main factors affecting performance are productivity, operating income, and the ability to develop new products.

$\mathrm{H}_{1}$ 5. A positive and meaningful relationship was found between (oi) and "Performance" $(r=0.704)$. Therefore, $\mathrm{H}_{1} 5$ hypothesis is accepted. It was stated that it is necessary for businesses to search for new markets and thus increase their income, which will increase their competitiveness (Tavşanc1, 2009;

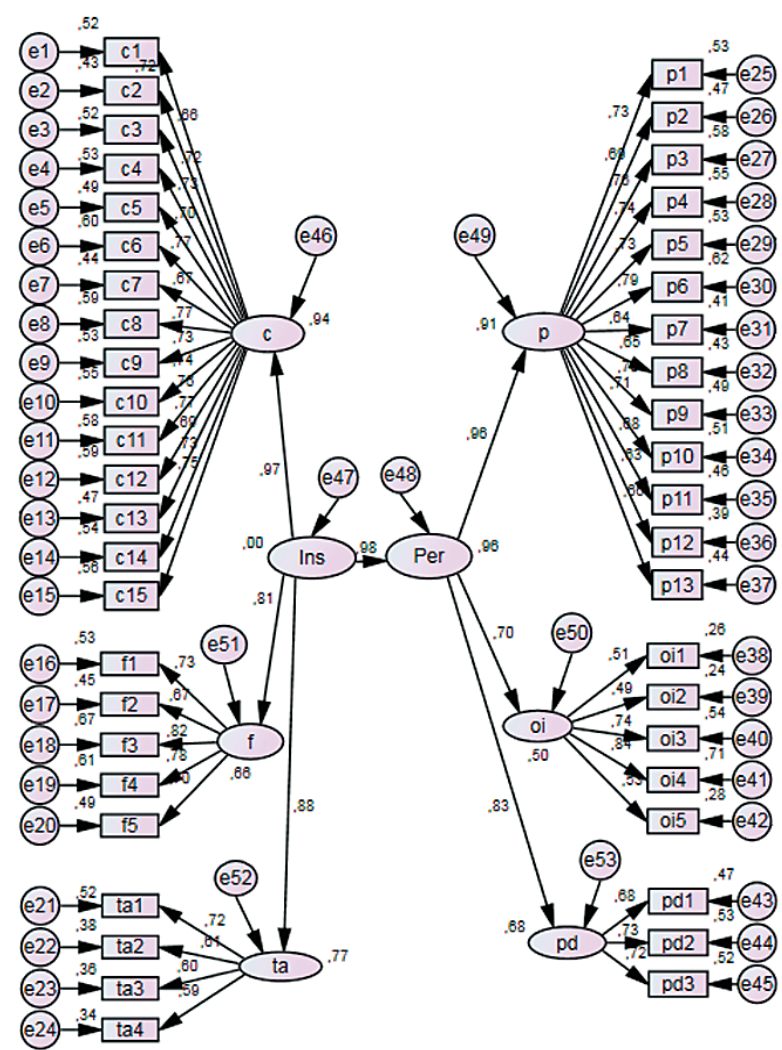

Figure 3 Path diagram related to PIS and PPS Slika 3. Dijagram toka za PIS i PPS

Yazıcıoğlu and Koç, 2009) and, having a high level of success, will positively affect the performance of the establishment (Yildız, 2010).

$\mathrm{H}_{1}$ 6. A positive and meaningful relationship was found between ( $\mathrm{pd})$ and "Performance" $(r=0.826)$. Therefore, $\mathrm{H}_{1} 6$ hypothesis is accepted. In literature, product development process is specified as an important factor that influences business performance positively (Keskin et al. 2016; Günday et al., 2011; Küçük ve Kocaman, 2014). In addition, there are studies stating that institutionalization increases the performance by compelling businesses to innovate (Tengilimoğlu et al., 2012; Onay and Vezneli, 2011).

$\mathrm{H}_{1}$ 7. As a result of evaluations and statistical analyses, it is concluded that an improvement in the institutionalization level of a business will result in improvements in performance $(r=0.98)$. Therefore, $\mathrm{H}_{1} 7$ hypothesis is accepted. As institutionalization will increase the satisfaction of employees, it will also have positive effects on performance and productivity (Çam, 2002; Erdil et al., 2004). In addition, there are studies stating that institutionalization increases the performance by compelling businesses to innovate (Tengilimoğlu et al., 2012; Onay and Vezneli, 2011) (Figure 3).

\section{CONCLUSIONS \\ 4. ZAKLJUČAK}

Through this methodological study, scales for perceived institutionalization and perceived perfor- 
mance in furniture and panel businesses operating in Turkey and the relationship between perceived institutionalization and perceived performance were explained by a model. As a result of the analyses, it was concluded that 1 unit of institutionalization improvement in a business results in a 0.96 -unit betterment (increase) in the performance of the business.

In consequence of analyses, a three-sub-dimensional structure was obtained through factor analyses results in both PPS (21 items) and PIS (24 items). While these sub-dimensions are identified as "Consistency" "Formalization" and "Transparency and accountability" in PIS, they are named as "Productivity", "Operating income" and "Product development" in PPS. Reliability analyses results for both scales and their sub-dimensions are at an acceptable level. It was seen that sub-dimensions of these scales demonstrate a positive meaningful relationship with each other and the total scale. Seven new hypotheses made related to these relationships were accepted.

It is thought that the study will be instructive in (i) determining perceived institutionalization and perceived performance in furniture and panel businesses, (ii) determining the variables influencing perceived institutionalization and perceived performance, (iii) detecting factors influencing perceived institutionalization and perceived performance in food, chemistry, automotive, machine and other manufacturing sectors.

\section{REFERENCES}

5. LITERATURA

1. Åkerman, M.; Kilpiö, A.; Peltola, T., 2010: Institutional change from the margins of natural resource use: The emergence of small-scale bioenergy production within industrial forestry in Finland. Forest Policy and Economics, 12 (3): 181-188.

http://doi.org/10.1016/j.forpol.2009.09.018.

2. Altınok, M.; Saçl1, C., 2009: The impact total quality management (TQM) on Productivity a framework implementation at a company producing panel furniture. Journal of Social and Economic Research, 9 (18): 63-86.

3. Apaydın, F., 2009: Institutional theory and institutionalization of organizations. Cumhuriyet University Journal of Economic and Administrative Sciences, 10 (1): 1-22.

4. Arbuckle, J. L., 2013: IBM SPSS AMOS 22 user's guide. IBM Software Group, Chicago.

5. Aydın, A., Tiryaki, S., 2018: Impact of performance appraisal on employee motivation and productivity in Turkish forest products industry: a structural equation modeling analysis. Drvna industrija, 69 (2): 101-111. https://doi.org/10.5552/drind.2018.1710.

6. Bentler, P. M., 2006: EQS 6 structural equations program manual. Multivariate Software Inc., California.

7. Byrne, B. M., 2010: Structural equation modeling with AMOS: Basic concepts, applications and programming. $2^{\text {nd }}$ Edition. Routledge Taylor and Francis Group, New York.

8. Çam, S., 2002: Learning organization and competitive advantage. Papatya Publishing, İstanbul.

9. Cindık, H.; Top, Y.; Karayılmazlar, S.; Akyüz, K. C., 1999: Analysis on the actual and potential condition of the middle and large sized forest products industry from a total quality management's perspective (A sample of the Karadeniz Region). Turkish Journal of Agriculture and Forestry, 23: 315-322.

10. Dayneko, D. V.; Gustafson, E. J., 2014: Institutional innovations in the forest industry in Russia: A case study of irkutsk province, miscellanea geographica-regional studies on development, 18 (4): 17-23. https://doi.org/10.2478/mgrsd-2014-0027.

11. Erdil, O.; Keskin, H.; İmamoğlu, S. Z.; Erat, S., 2004: The relationship between supervision style, working conditions, co-workers behavior, recognition and job satisfaction: A field research on textile firms. Doğus University Journal, 5 (1): 17-26. http://doi.org/10.31671/dogus.2019.303.

12. Fornell, C.; Larcker, D. F., 1981: Evaluating structural equation models with unobservable variables and measurement error. Journal of Marketing Research, 18 (1): 39-50.

13. Fuchs, E. P.; Anderson, J. E., 1987: The institutionalization of cost-benefit analysis. Public Productivity Review, 10 (4): 25-33. https://doi.org/10.2307/3380247.

14. Gedik, T., 2010: A fieldwork on the assessment and increasing of the employee's performance in forest products industry sector (Furniture and panel factories case). Ph.D. Thesis. Karadeniz Technical University, Institute of Science, Forest Industry Engineering, 339 pp.

15. Günday, G.; Ulusoy, G.; Kılıç, K.; Alpkan, L., 2011: Effects of innovation types on firm performance. International Journal of Production Economics, 133 (2): 662676. https://doi.org/10.1016/j.ijpe.2011.05.014.

16. Gürüz, D.; Gürel, E., 2009: Management and organization. $2^{\text {nd }}$ printing. Nobel Publishing, Ankara.

17. Han, B.; Tang, Y.; Yang, L., 2016: Public information and uninformed trading: implications for market liquidity and price efficiency. Journal of Economic Theory, 163 (C): 604-643. https://doi.org/10.1016/j.jet.2016.02.012.

18. Huang, C. C.; Wang, Y. M.; Wu, T. W.; Wang, P. A., 2013: An empirical analysis of the antecedents and performance consequences of using the moodle platform. International Journal of Information and Education Technology, 3 (2): 217-221. https://doi.org/10.7763/IJIET.2013.V3.267.

19. Huntington, S. P., 1973: Political order in changing societies. $7^{\text {th }}$ printing. Yale University Publishing, London.

20. İstek, A.; Özlüsoylu, İ.; Kızılkaya, A., 2017: Turkish wood based panel sector analysis. Journal of Bartın Faculty of Forestry, 19 (1): 132-138. http://doi.org/10.24011/barofd.297231.

21. Kalaycı, Ş., 2009. SPSS applied multivariate statistics techniques. $4^{\text {th }}$ printing. Asil Publishing, Ankara, Turkey.

22. Keskin, H.; Zehir, S.; Ayar, H., 2016: Relationship between market orientation and firm performance: The mediatıng role of differentiation strategy. Doğus University Journal, 17 (1): 111-127. http://doi.org/10.31671/dogus.2018.46.

23. Kırklıkçı, A. B.; Gedik, T., 2019: Performance perception of furniture and panel factories in Turkey. Düzce University Journal of Science and Technology, 7 (3): 1073-1086. http://doi.org/10.29130/dubited.489282.

24. Knight, J., 1992: Institutions and social conflict. Cambridge University Publishing, Cambridge.

25. Koç, K. H.; Dilik, T.; Kurtoğlu, A., 2017: A strategic overview vision on Turkey forest products industry. IV. National Congress of Forestry, Antalya, Turkey, 15-16 Nov, 1, 483-495.

26. Küçük, O.; Kocaman, G., 2014: The relationship between customer orientation, innovation orientation and business performance: An implementation. International Journal of Social Science, 29: 37-52. http://doi.org/10.9761/JASSS2575. 
27. Onay, M.; Vezneli, Z., 2011: Noninstituional of family companies and depersonelization of following generation. Journal of Organization and Management Sciences, 3 (2): 167-176.

28. Şanal, M., 2011: A study of family businesses on institutionalization and instutional entrepreneurship. Ph.D. Thesis. Çukurova University, Institute of Social Sciences, Business, $140 \mathrm{pp}$.

29. Sarıkahya, M., 2012: Effect of state subsidies granted to smes in furniture industry on the companies (Ankara example). Journal of Polytechnic, 15 (4): 177-183. http://doi.org/10.2339/2012.15.4, 177-183.

30. Schermelleh-Engel, K.; Moosbrugger, H.; Müller, H., 2003: Evaluating the fit of structural equation models: Tests of significance and descriptive goodness-of-fit measures. Methods of Psychological Research Online, 8 (2): 23-74.

31. Selznick, P., 1996: Institutionalism "old" and "new", administrative science quarterly, $40^{\text {th }}$ Anniversary Issue, 41(2): 270-277. https://doi.org/10.2307/2393719.

32. Serin, H.; Şahin, Y., 2018: Evaluation of furniture sector in diyarbakır province by SWOT analysis. Turkish Journal of Forest Science, 2 (1): 83-90. http://doi.org/10.32328/turkjforsci.414373.

33. Sözbilen, G., 2012: The effect of institutionalization on corporate entrepreneurship: An empirical study at accomodation establishments in Nevsehir. Master Thesis. Nevşehir University, Institute of Social Sciences, Business, $139 \mathrm{pp}$.

34. Tavşanc1, S., 2009: A Research on the effect of institutionalization level on competitiveness in firms. Ph.D Thesis. Dokuz Eylül University, Institute of Social Sciences, Business, $164 \mathrm{pp}$.

35. Tengilimoğlu, D.; Iş1k, O.; Akbolat, M., 2012: Health business management. $4^{\text {th }}$ printing. Nobel Publishing, Ankara.

36. Tuppura, A.; Toppinen, A.; Jantunen, A., 2013: Proactiveness and corporate social performance in the global forest industry. International Forestry Review, 15 (1): 112-121. https://doi.org/10.1505/146554813805927147.

37. Uygun, Ö.; Kahveci, T. C.; Taşkın, H.; Priştine, B. A., 2013: Model for measuring institutionalization level of SMEs. The Online Journal of Science and Technology, 3 (4): 126-137.

38. Wanat, L.; Potkanski, T.; Chudobiecki, J.; Mikolajczak, E.; Mydlarz, K., 2018: Intersectoral and intermunicipal cooperation as a tool for supporting local economic development: Prospects for the forest and wood-based sector in Poland. Forests, 9 (9): 1-12. http://doi.org/10.3390/f9090531.

39. Yaşar, M., 2014: Attitudes toward statistics scale: validity and reliability study. Pamukkale University Journal of Education, 36: 59-75. http://doi.org/10.9779/PUJE640.

40. Yaşlıoğlu, M. M., 2017: Factor analysis and validity in social sciences: application of exploratory and confirma- tory factor analyses. İstanbul University Journal of the School of Business, 46: 74-85.

41. Yazıcıŏlu, İ.; Koç, H., 2009: A comparative study into the level of institutionalisation of family-run enterprises. Selçuk University Journal of Institute of Social Sciences, 21: 497-507.

42. Y1ldiz, D., 2010: The effect of customer relation management (CRM) aplications on customer's performance (A business example). Master Thesis. Dumlupınar University, Institute of Social Sciences, Business, $107 \mathrm{pp}$.

43. Y1lmaz, E. F., 2006: The effect of performance evaluation system on business productivity and a case study. Master Thesis. Trakya University, Institute of Social Sciences, Business, 208 pp.

44. Zhu, Q.; Sarkis, J., 2007: The moderating effects of institutional pressures on emergent green supply chain practices and performance. International Journal of Production Research, 45 (18/19): 4333-4355. http://doi.org/10.1080/00207540701440345.

45. ***IBM Corp., 2013: IBM SPSS statistics for windows, version 22.0. IBM Corp., Armonk.

46. ***IIBA, 2018: Independent industrialists' and businessmen's association. Durable consumer goods furnitere and forest products sector report, http://www.musiad.org. tr/F/Root/Pdf/DTM_Mobilya_ve_Orman_urunleri_Sektor raporu.pdf (Accessed Aug. 4, 2019).

47. ***JFIB, 2019: Journal of Forest Industry Businessmen, http://www.orsiad.com.tr/levha-sektor-analizi.html (Accessed Aug. 4, 2019).

48. ***TMT, 2020: Turkey Ministry of Trade. Furniture Sector Report.

https://ticaret.gov.tr/data/5b87000813b8761450e18d7b/ Mobilya\%20Sekt\%C3\%B6r\%20Raporu\%202020.pdf (Accessed Aug. 4, 2019).

49. ***UCCET, 2015: The Union of Chambers and Commodity Exchanges of Turkey. Forest Products Sector Council Report, Publishing No: 2016/281.

50. ${ }^{* * *}$ UCCET, 2017: The Union of Chambers and Commodity Exchanges of Turkey. Furniture Products Sector Council Report, Publishing No: 2018/304.

51. ${ }^{* * * W M B A}, 2017$ : Woodworking Machinery and Side Industries Businessmen Association Magazine, http:// www.aimsaddergisi.com/dergipdf/AIMSADDergisiSayi15.pdf (Accessed Sep. 9, 2019).

\section{Corresponding address:}

\section{Assist. Prof. AHMET BORA KIRKLIKÇI}

Karamanoğlu Mehmetbey University

Vocational School of Technical Sciences

Production Quality Control Program

70000 Karaman, TURKEY

e-mail: borakirklikci@kmu.edu.tr 